\begin{tabular}{|c|c|}
\hline $\begin{array}{l}\text { Jurnal Pakarena } \\
\text { Volume } 4 \text { Nomor 1, Juni } 2019 \\
\text { e-ISSN: 2550-102X dan p-ISSN: 1693-3990 }\end{array}$ & PAKARENA \\
\hline $\begin{array}{l}\text { (c) T) This work is licensed under a Creative Commons Attribution } \\
4.0 \text { International License }\end{array}$ & Arrum \\
\hline
\end{tabular}

\title{
BENTUK, FUNGSI, DAN MAKNA PAMOR SENJATA KAWALI DALAM MASYARAKAT BUGIS
}

\section{Satriadi}

Keywords :

Senjata Kawali;

Pamor; Bugis;

\section{Corespondensi Author}

Desain Komunikasi Visual, Universitas Negeri Makassar, Fakultas Seni dan Desain Jln. Dg. Tata Kampus UNM

Parangtambung satriadi@unm.ac.id

\begin{abstract}
ABSTRAK
Kawali merupakan warisan kebudayaan fisik dan juga merupakan produk kesenian berupa senjata tikam jarak pendek dengan bilah yang hanya memiliki satu sisi tajam dan ujung yang runcing. Kawali secara utuh memiliki tiga elemen pokok yaitu bilah, wanoa dan pangulu. Masing-masing elemen tersebut memiliki bentuk dan makna tersendiri. Bilah merupakan elemen paling pokok karena di dalamnya terdapat motif pamor yang mengadung pesan atau makna simbolik yang dijadikan pedoman masyarakat pendukungnya, dalam hal ini masyarakat Bugis. Oleh karena itu, ada dua aspek kesenian yang perlu diperhatikan dalam menganalisis bentuk dan makna simbolik motif pamor pada kawali yaitu konteks estetika atau penyajian yang mencakup bentuk dan gaya, kedua adalah konteks makna (meaning) yang mencakup pesan dan kaitan dengan simbol-simbolnya (simbolic value). Penelusuran bentuk dan makna motif pamor melalui interpretasi analsis dengan pendekatan Estetika Nusantara dan penjelasan emik dalam kebudayaan, sehingga diketahui bahwa eksistensi pamor kawali adalah selain sebagai motif penghias bilah juga sebagai pesan yang menggambarkan kehidupan yang ideal dalam masyarakat Bugis.
\end{abstract}

\section{ABSTRACT}

Kawali is the physical and cultural heritage is also a product of art in the form of short-range stabbing weapons with blades that have only one sharp edge and a pointed end. Kawali as a whole has three main elements, namely bilah, wanoa and pangulu. Each of these elements has its own form and meaning. Bilah is the most essential element because it constitutes a pamor motive having message or symbolic meaning guiding the supporting people, in this case the Bugis people. Therefore, there are two aspects of art that need to be considered in analyzing the shape and symbolic meaning pamor motive in kawali that context aesthetic or presentation that includes the shape and style, the second is the context of meaning (meaning) that includes the message and the link with the symbols (symbolic value). Search form and meaning through interpretation pamor motive to approach the analysis and Nusantara Aesthetics explanation emic in the culture, so it is known that the existence of kawali pamor is other than as a motive trimmer 
blades as well as a message that describes the ideal life in Bugis people.

\section{PENDAHULUAN}

Sulawesi selatan merupakan wilayah administrasi yang didukung oleh empat etnis besar yaitu Bugis, Makassar, Mandar dan Toraja (Mattulada, 1995:5). Bugis merupakan etnis yang memiliki populasi yang paling besar dan menduduki wilayah yang luas. Etnis Bugis memiliki kebudayaan yang unik dan spesifik. Salah satu keunikan dan kespesifikan kebudayaannya tercermin dalam sistem pengetahuan mengenai senjata tradisional. Senjata tradisional yang identik dengan Bugis adalah badik, dimana dalam istilah lokal dikenal dengan sebutan kawali. kawali merupakan wujud kebudayaan Bugis dalam bentuk artefak berupa senjata tradisional.

Koentjaraningrat menyebutkan, ada tiga wujud kebudayaan: 1) wujud kebudayaan sebagai suatu kompleks dari ide-ide, gagasan, nilai-nilai, norma-norma, peraturan dan sebagainya; 2) wujud kebudayaan sebagai suatu kompleks aktivitas kelakuan berpola dari manusia dalam masyarakat; 3) wujud kebudayaan sebagai benda-benda hasil karya manusia, berupa kebudayaan fisik yang berbentuk nyata dan merupakan hasil karya masyarakat. Ketiga wujud kebudayaan tersebut oleh Koentjaraningrat dinyatakan sebagai sistem-sistem yang erat kaitannya satu sama lainnya, dan dalam hal ini sistem yang paling abstrak (ideas) seakan-akan berada di atas untuk mengatur aktivitas sistem sosial yang lebih kongkrit, sedangkan aktivitas dalam sistem sosial menghasilkan kebudayaan material (artifact). Sebaliknya sistem yang berada di bawah dan bersifat konkrit memberi energi kepada yang di atas (1986:186-188). Adanya ide dan gagasan mengakibatkan terjadinya aktivitas yang menghasilkan suatu karya (kebudayaan fisik). Selanjutnya kebudayaan fisik berpengaruh terhadap lingkungan tertentu sehingga makin lama makin menjauhkan manusia dari kondisi asli lingkungan alam, hal yang selanjutnya mempengaruhi pola-pola berpikirnya dan juga cara bergaul, dan cara bertindak. Dalam hal ini, kawali merupakan artifak kebudayaan masyarakat Bugis yang memuat idea dan digunakan dalam aktivitas sehari-hari serta mempengaruhi aktivitas sosial masyarakat Bugis, oleh karena itu secara umum penelitian ini menggunakan pendekatan budaya untuk mengkaji permasalahan yang diajukan dalam penelitian.

\section{METODE}

Metode penelitian yang dipilih untuk memperoleh data-data dan informasi, menginventarisasi, mengolah dan menganalisisnya yaitu metode penelitian kualitatif. Penelitian kualitatif tidak menekankan pada kuantum atau jumlah, jadi lebih menekankan pada segi kualitas secara alamiah karena menyangkut pengertian, konsep, nilai serta ciri-ciri yang melekat pada objek penelitian lainnya. Penelitian ini akan mendeskripsikan tentang eksistensi kawali, bentuk pamor dan maknanya. Agar menghasilkan sebuah hasil penelitian yang relevan dengan tujuannya, maka rencana penelitian ini diperlukan metode penelitian berupa metode; (1) penentuan sumber data, (2) teknik pengumpulan data, dan (3) analisis data.

\section{Sumber data}

a. Karya kawali

Karya kawali yang dikaji merupakan karya-karya kawali yang tersebar di beberapa daerah di wilayah Bugis. kawali-kawali yang menjadi sumber referensi antara lain koleksi pribadi Andi Ancu, Andi Basri, Tenri Ewa, Imran Syahruddin, dan Galery Adi Pusaka. Sumber data berupa ini dapat digunakan untuk menganalisis berbagai varian bentuk bilah dan bentuk pamornya.

\section{b. Nara Sumber}

1) Panre bessi/mpu

Panre bessi adalah orang yang ahli dalam menempa bilah kawali. Data yang diharapkan dari Panre bessi ini adalah data tentang proses dan teknik pembuatan bilah kawali, mulai pada tahap persiapan penempaan hingga pasca penempaan, selain itu juga diharapakn data mengenai teknik-teknik pembentukan pamor. Adapun panre yang dimaksud adalah A. Tenri Polo Jiwa, Panre Lawu, Panre Co'tang.

2) Perajin wanoa dan hulu 
Sebuah kawali yang utuh adalah kawali yang dilengkapi dengan wanoa dan pangulu. Data yang diharapkan dari perajin ini adalah proses dan teknik pembuatan wanoa dan pangulu dalam berbagai variasi bentuk dan motif ragam hias yang diterapkan. Adapun orang yang dimaksud adalah Daeng Aries. Data yang diperoleh dari narasumber ini adalah bahan dan teknik pembuatan kelengkapan kawali.

3) Budayawan

Kawali sangat berkaitan erat dengan kebudayaan Bugis, maka dibutuhkan data dari seorang budayawan untuk menjelaskan bagaimana keberadaan kawali dalam kaitannya dengan aktivitas sosial masyarakat yang berkaitan dengan kawali, sejarah kawali dan bagaimana peranannya dari dulu hingga sekarang. Adapun budayawan yang dimaksud adalah A. Kahar Wahid, Andi Baso Bone, Andi Darwis Petta Mabbangkungnge, Halilintar Latief, Andi Singke, Andi Basri, dan Andi Haedar.

4) Kolektor

Kolektor merupakan orang yang menyimpan dan merawat berbagai jenis kawali. Data yang diharapkan dari kolektor adalah berupa dokumentasi mengenai pamor kawali, serta makna dari pamor tersebut. Adapun kolektor yang dimaksud adalah Andi Halilintar Latif, Imran Syahruddin, Andi Haedar, Andi Basri, dan Andi Andu.

\section{c. Dokumen atau arsip}

Dokumen atau arsip dalam penelitian ini adalah data-data tertulis mengenai semua materi yang terkait dengan pokok permasalahan dalam penelitian ini yang didapat dari studi pustaka dan literatur. Dokumen berupa catatan lontara' dan arsip-arsip berupa foto-foto lama mengenai bentuk-bentuk pamor atau peristiwaperistiwa yang berhubungan dengan penggunaan kawali. Adapun dokumen atau arsip yang dimaksud adalah Lontara Pangurissengen Appasisikeng yang telah ditransliterasi, berisi tentang cara-cara melihat baik dan buruknya sisi' dari sebuah senjata, termasuk di dalamnya kawali serta lontara' pananrang yang berisi hari-hari yang dianggap baik untuk melakukan suatu aktivitas tertentu.

\section{Teknik pengumpulan data}

Salah satu tujuan penelitian ini adalah untuk mengetahui bentuk motif pamor dan maknanya pada bilah kawali, sehingga untuk mendata motif-motif pamor, beserta unsur pembentuknya digunakan metode observasi, dan untuk meyakinkan data observasi, dilakukan wawancara dan studi kepustakaan. Metode observasi dapat diartikan sebagai pengamatan dan pencatatan secara sistematik terhadap fenomena-fenomena yang diselidiki. Untuk memperlancar penelitian dan agar dapat berjalan secara sistematis maka dibuat tahapantahapan penelitian yang meliputi; (1) tahap penentuan sasaran penelitian; (2) tahap pengumpulan data dan (3) tahap pembahasan data. Sasaran penelitian ini adalah seluruh bentuk pamor rekan dan tiban yang melekat pada bilah kawali. Penelitian ditujukan untuk mengadakan indetivikasi bentuk motif pola dan pola pamor dengan mengenali, menandai, membuat klasifikasi dan menginterpretasikan. Agar dapat memperoleh data seperti yang diharapkan sesuai dengan rumusan masalah dalam penelitian ini, maka perlu digunakan suatu metode pengumpulan data yang tepat. Metode pengumpulan data yang digunakan adalah studi pustaka, metode observasi, metode wawancara dan dokumentasi.

\section{a. Studi Pustaka}

Studi pustaka dilakukan dengan mengumpulkan sumber pustaka yang berhubungan dengan masalah penelitian yang kemudian dengan cara membaca, lalu mencatat yang dianggap penting yang berhubungan dengan masalah penelitian, dan kalau diperlukan dilakukan translate bahasa, karena data-data manuskrip dan naskah kuno umumnya berbahasa Bugis dengan huruf lontara'. Langkah-langkah dalam studi pustaka diawali dengan pemilahan data-data pustaka yang berupa manuskrip, buku-buku kuno yang sudah tidak diterbitkan dan buku-buku baru yang berhubungan dengan tema yang sedang dikaji. Setelah dilakukan pemilahan dan pendataan dilakukan pembacaan dan pencatatan yang dianggap penting.

\section{b. Observasi}

Metode observasi adalah metode yang digunakan untuk mengamati sesuatu, seseorang, suatu lingkungan, atau situasi secara tajam terinci, dan mencatatnya secara akurat dalam beberapa cara. Metode observasi dalam penelitian seni dilaksanakan untuk memperoleh data tentang karya seni dalam suatu kegiatan dan situasi yang relevan dengan masalah penelitian (Rohendi, 2011:182). Metode 
observasi juga merupakan salah satu metode yang dapat digunakan untuk keperluan identifikasi. Hal tersebut karena cara kerja metode observasi menyadarkan pada pengamatan dan pencatatan langsung pada objek yang bersangkutan.

Metode observasi yang digunakan dalam penelitian ini adalah metode observasi secara langsung, yaitu pengamatan yang dilakukan secara langsung seksama, dan mendetail untuk mengetahui rupa pamor yang melekat pada bilah kawali, kemudian dilakukan pencatatan, pengukuran dan pendokumentasian melalui pemotretan, sedangkan bentuk-bentuk yang tidak dapat dijangkau dengan dokumentasi potret maka dilakukan pembuatan sketsa terhadap objek yang diteliti sehingga data-data yang diinginkan dapat diperoleh dengan baik.

\section{c. Wawancara}

Wawancara adalah suatu teknik yang digunakan untuk memperoleh informasi tentang kejadian yang oleh peneliti tidak dapat diamati sendiri secara langsung, baik karena tindakan atau peristiwa yang terjadi dimasa lampau ataupun karena peneliti tidak diperbolehkan hadir ditempat kejadian itu (Rohendi, 2011:208). Wawancara dilakukan dengan cara tanya jawab dengan narasumber. Wawancara dilakukan untuk meyakinkan dan memperoleh data-data penelitian yang berhubungan dengan keberadaan kawali dalam masyarakat Bugis, dan makna motif pamor pada bilah kawali.

Metode wawancara yang dilakukan adalah metode wawancara mendalam (in deep interviewing). Wawancara mendalam lebih menyerupai percakapan dibanding dengan wawancara terstruktur secara formal. Narasumber yang dipilih berdasarkan pengalaman dan pengetahuan yang mumpuni agar bisa mendapat informasi yang benar, lengkap dan mendalam.

Wawancara dilakukan pada informan yang dianggap memiliki kompetensi dan memahami permasalahan studi, seperti para етри atau panre bessi, para pakar kawali dan para pecinta atau kolektor kawali. Wawancara yang dilakukan lebih bersifat terbuka ini akan memberi peluang keleluasaan terhadap penggalian informasi dengan fokus-fokus tertentu sehingga diperolah informasi yang mendalam terkait dengan unit analisisnya.

\section{d. Dokumentasi}

Dokumen merupakan penggalian data dari arsip-arsip atau data-data dokumen berupa gambar, foto ataupun tulisan. Penggalian data dokumen dilakukan dengan beberapa langkah, antara lain pemilahan dan pengklasifikasian dokumen yang berupa arsip atau data-data, foto atau ilustrasi gambar sesuai dengan tema penelitian kemudian dilakukan pencatatan dari data atau arsip-arsip tersebut, dilakukan repro ulang melalui foto dan scaner, dan apabila tidak dapat diperoleh hasil maksimal diperlukan pembuatan ilustrasi dengan cara digambar dengan tangan secara langsung.

\section{Teknik Analisis Data}

Tahap analisis data bertujuan untuk mendapatkan ketetapan kenyataan dan penetapan konsep sebagai konsep pengklarifikasian data yang didapatkan di lapangan sebagai data awal. Setelah itu datadata tersebut direduksi. Reduksi data merupakan komponen pertama dalam analisis data, meliputi proses selektif pemfokusan, penyederhanaan, dan abstraksi data dari catatan lapangan (Sutopo, 2006:9). Analisis data yang dilakukan bersifat induktif. Dalam analisis induktif data yang diperoleh disimpulkan dan dikomparasikan dengan data-data lain yang berkaitan dengan tujuan penelitian dengan beberapa tahapan analisis. Agar dapat menjawab setiap rumusan masalah pada rencana penelitian ini, secara eksplisit penulis menggunakan pendekatan budaya untuk mengetahui kebudayaan dan adat istiadat masyarakat Bugis secara komprehensif. Penelitian ini menggunakan analisis dengan dua model analisis data, yaitu interaksi analisis dan Interpretasi analisis.

\section{a. Interaksi Analisis}

Analisis dengan pendekatan interaksi analisis digunakan untuk menjawab rumusan masalah pertama dan kedua yaitu bagaimana eksistensi kawali dan bagaimana tanggapa masyarakat mengenai pamor rekan dan pamor tiban. Untuk menjawab rumusan masalah tersebut maka interaksi analisis ini ditunjang oleh bidang keilmuan lain yaitu sejarah untuk mengetahui latar belakang munculnya kawali dalam masyarakat Bugis, sosiologi untuk mengetahui aktivitas kehidupan masyarakatnya dan antropologi untuk mengetahui lingkungan serta adat istiadat masyarakat Bugis. 
Karakteristik data yang digunakan dalam interaksi analisis menekankan pada penggunaan data emik. Riset emik merupakan penelitian yang berlandasakan data yang didapatkan dari lapangan berupa wawancara dari narasumber dan pengamatan di lokasi penelitian. Selain itu digunakan pula data etik sebagai bentuk analisis yang bersumber dari kajian pustaka dan dokumen yang relevan dengan penelitian.

Proses interaksi analisis data meliputi tiga alur kegiatan sebagai suatu sistem, yaitu (1) reduksi data, (2) sajian data, dan (3) penarikan kesimpulan/verifikasi (Miles dan Huberman, 1992:24). Ketiga komponen analisis tersebut aktivitasnya dilakukan dalam bentuk interaktif dengan proses pengumpulan data sebagai suatu proses siklus (Sutopo, 2006:117-120). Teknik triangulasi yang dipakai, triangulasi data dan triangulasi metode. Triangulasi data mengarahkan penelitian untuk menggunakan beberapa data sejenis sebagai pembanding dengan demikian data yang satu bisa lebih teruji jika dibanding dengan data sejenis yang diperoleh dari sumber lain, sedangkan teknik triangulasi metode dilakukan dengan cara membandingkan data sejenis dengan pengumpulan data yang berbeda (Sutopo, 2006: 71-72).

Proses model analisis interaktif tersebut dapat digambarkan dengan skema berikut :

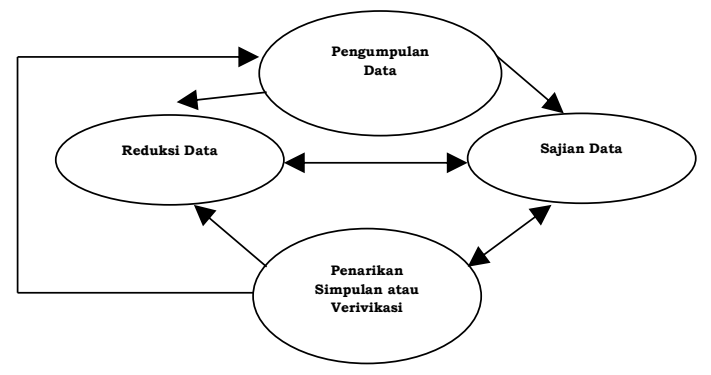

Bagan 2. Model Analisis Interaktif (Sutopo, 2006:120)

\section{b. Interpretasi analisis}

Analisis dengan pendekatan interpretatif analisis digunakan untuk menjawab rumusan masalah ketiga yaitu bagaimana bentuk motif pamor pada kawali dan maknanya. Analisis interpretasi pada penelitian ini menggunakan pendekatan Konsep Estetika Nusantara yaitu untuk menjelaskan keberadaan bentuk dan makna simbolik pamor pada kawali. Konsep estetika kesenian Nusantara memperlihatkan sifatnya yang khas, yaitu dari mistis hingga religius. Penciptaan karya seni yang bersifat simbolik merupakan ciri dan karakter dari estetika Nusantara (Dharsono, 2007: 31). Estetika Nusantara selalu berhubungan dengan nilai tontonan (estetis), tuntunan (falsafah) dan dipengaruhi oleh sugesti alam, karena manusia merasa menjadi bagian dari alam. Karakteristik inilah yang membedakan antara pandangan filsafat modern dan filsafat Nusantara. Filsafat Nusantara mencerminkan hubungan mikrometa-makrokosmos dan mendudukan diri manusia menjadi bagian dari alam, sehingga berpengaruh terhadap suatu pencapaian karakter tertentu melalui simbol yang merupakan ekspresi yang bersifat kultural dan dasar struktur yang terencana (Yuwono, 2010: 39).

Karakteristik dari visualisasi motif tradisional Nusantara dijelaskan oleh Dharsono yang berpijak pada pola motif batik sebagai berikut: pola/motif disusun berasarkan pola yang sudah baku yang terdiri dari bagian, yaitu; 1) 'motif utama', merupakan unsur pokok pola, berupa gambar-gambar bentuk tertentu karena merupakan unsur pokok, maka disebut pula ornamen pokok (utama). 2) 'motif pengisi', merupakan pola berupa gambar-gambar untuk mengisi bidang, bentuk lebih kecil dan turut membentuk artti atau jiwa pola tersebut, dan 3) 'isen', untuk memperindah pola secara keseluruhan, baik ornamen pokok maupun ornamen pengisi diberi isian berupa hiasan: titik-titik, garis-garis, gabungan titik dan garis (Dharsono,2007:87).

Dalam sebilah kawali mengandung dua aspek yaitu aspek tontonan (keindahan) dan tuntunan (ajaran/ filosofis). Aspek tontonan dapat dilihat dari struktur kawali yang tediri dari wanoa, laca' dan pangulu'. Diantara tiga elemen tersebut bilah kawali merupakan elemen pokok karena di dalamnya termuat pamor yang mengandung motif yang menggambarkan nilai fisofis (aspek tuntunan. Motif utama kemudian dimaknai secara filosofis dengan merelasikan dengan perilaku dan kepercayaan masyarakat yang berhubungan dengan motif utama. Oleh karena itu, dapat dikatakan bahwa interpretasi dilakukan dengan pendekatan estetika Nusantara dengan penjelasan emik dalam kebudayaan. 


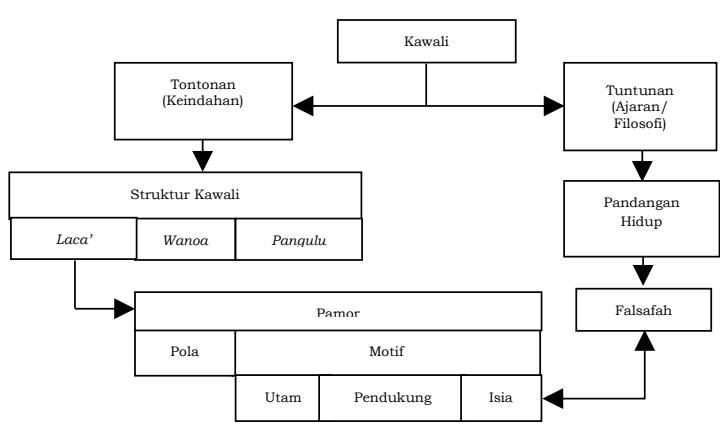

Bagan 3. Skema interpretasi analisis dengan konsep estetika Nusantara

\section{HASIL DAN PEMBAHASAN Fungsi Kawali dalam Masyarakat Bugis}

Masyarakat tradisional lebih menekankan pada aspek-aspek simbolis religius yang magis dan baru kemudian mengolahnya menjadi suatu benda yang memenuhi fungsi sosial dan teknomiknya (fungsi fisik) sebagai suatu alat untuk beradaptasi atau menaklukkan lingkungannya demi menjaga lingkungan hidupnya (Yuwono, 2011:181). Sebuah benda diciptakan manusia setidaknya mewakili tiga fungsi dasar yaitu fungsi teknomik, fungsi sosial, dan fungsi religius.

\section{Fungsi Teknomik}

Fungsi awal kawali adalah sebagai senjata. Kawali merupakan senjata tajam yang secara fungsi guna (teknomik) dapat digunakan sebagai senjata tikam yang efektif dalam pertarungan jarak dekat. Dalam budaya Bugis, kawali tergolong sebagai senjata assigajangen, artinya senjata untuk saling tikam (Andi Basri, wawancara 2 Agustus 2015).

Peran kawali sebagai kelengkapan senjata perang juga banyak dijumpai dalam cerita dan tulisan-tulisan sejarah. Dalam sejarah kerajaan Bone dikatakan bahwa

"Pertempuran segera berkobar tatkala pasukan pendaratan tersebut mencapai puncak sebuah bukit bersemak-semak. Ratusan prajurit Bone menghadang dengan tembakan-tembakan gencar. Tembak menembak itu disusul degan pergulatan sengit beberapa jam lamanya dengan mempergunakan keris, kawali, kalewang dan tombak..." (Palloge, 1990:199).

Keterangan tersebut memberi gambaran mengenai perlawanan pasukan Bugis menghadapi Belanda di dalam hutan dengan bersenjatakan salah satunya adalah kawali.
Pengejaran Belanda masih tetap berlangsung terhadap Raja Bone Lapawawoi Arung Segeri yang dilindungi oleh panglima perangnya Petta Ponggawae, meskipun Belanda sudah menduduki istana kerajaan Bone. Bagi Belanda sebelum menangkap sang raja dan panglima perangnya, berarti belum menguasai kerajaan Bone sepenuhnya. Akhirnya, tanggal 18 November 1905, panglima perang Bone Petta Ponggawae tewas tertembak di bagian dada dengan senapan dan kawali tergenggam kuat di tangan (Palloge, 1990:203-204).

Kawali dengan fungsi sebagai senjata biasanya tidak mementingkan keindahan pamor, karena adanya kepercayaan masyarakat bahwa tidak ada pamor yang membunuh (degaga pamoro pawunu), bahkan terdapat tuturan masyarakat di Bone mengatakan bahwa nappemmaliangngi to-bone we pake luwu, artinya bagi orang Bone pemali mengunakan kawali luwu (Andi Basri, wawancara 2 Agustus 2015). Keterangan tersebut memberikan konotasi bahwa kawali sebagai senjata pembunuh tidak mementingkan pamor sebagaimana kawali Luwu yang banyak mengandung pamor yang indah. Namun kawali sebagai senjata pembunuh lebih mementingkan ketajaman dan racun yang dikandungnya (amosoangeng) (Andi Singke, wawancara 31 Juli 2015).

\section{Fungsi sosial}

Kawali sebagai simbol kedewasaaan. Gambaran sosial tentang sosok laki-laki ideal adalah mereka yang sudah menyelipkan kawali dipingangnya, sebagaimana tuturan yang mengatakan bahwa tania orowane narekko de nakkawali, arinya bukan laki-laki jika tidak menyelipkan kawali di pinggang. Salah satu penanda bahwa seorang laki-laki Bugis sudah utuh adalah ketika telah memiliki baine (istri), bola (rumah), tana (tanah persawahan atau kebun), anyareng (kuda/kendaraan) dan parewa bessi (kawali) (Kahar Wahid, wawancara 15 Maret 2018).

Kawali sebagai penanda garis keturunan. kawali pusaka milik suatu keluarga dapat diwariskan kepada anak keturunan dari keluarga tersebut. Dalam tradisi orang Bugis, kawali pusaka biasanya diberikan kepada anak laki-laki tertua dalam keluarga. kawali yang telah diwariskan disebut dengan kawali mana'. Apabila semua anaknya perempuan, maka kawali diwariskan kepada menantu laki-laki (Kahar Wahid, wawancara 15 Maret 2018). 
Pewaris kawali mana' secara turun temurun dilakukan secara lisan, misalnya seorang ayah cukup mengatakan kawali ini akan diwariskan kepada anak laki-laki tertua dalam keluarga. Orang yang mewarisi kawali mana' akan berusaha merawat mana' yang diterimanya dengan penuh hati-hati dan selalu mengikuti tradisi yang berlaku dalam lingkungan keluarganya. Biasanya para pewaris kawali mana' tidak mengetahui secara tepat asal-usul mana' tersebut, sehingga semakin lama sejarah pusaka tersebut semakin kabur, bahkan dibumbui dengan cerita-cerita mitos kemunculannya.

Kawali sebagai simbol status. Telah dijelaskan pada sub bab sebelumnya (sub-bab mengenai kawali dan hirarki) bahwa status seseorang dalam masyarakat dapat diketahui dari kawali yang disandangnya. Bentuk kawali dan bahan-bahan yang digunakan untuk elemen-elemennya menggambarkan kemampuan finansial pemiliknya. kawali jenis raja hanya boleh dimiliki oleh bangsawan (anakarung) (Senewe, dalam Ubbe, 2011:161). Bahkan kawali dengan pamor tertentu dibuat ketika seorang anak bangsawan akan menikah, misalnya pamor gamacca (Ewa, 2014:34)

Kawali sebagai alat peraga. Setiap pasukan yang akan diberangkatkan berperang maka terlebih dahulu dilakukan sumpah setia prajurit kepada sang raja. Sumpah setia ini disebut dengan mangaru' atau osong. Andi Ardiman mengatakan bahwa osong terbagi atas tiga jenis yaitu (1) osong pakkanna, ialah pernyataan kesetiaan kepada raja pada waktu kerajaan menyatakan perang terhadap musuh. Biasanya menggunakan properti kawali yang diacungkan secara vertikal saja, (2) osong pattuppu, yaitu pernyataan yang digunakan bila menjemput tamu kerajaan. Pattuppu artinya tetamu, dan (3) osong pakkuru' sumange', yaitu pernyataan yang ditujukan kepada raja yang baru terpilih bertujuan untuk memberi semangat dalam memimpin rakyat. Orang yang melakukan osong disebut mangosong' yakni bersumpah, berikrar, menyatakan kesetiaan. Seorang yang melakukan osong' haruslah berpakaian adat, mengucapkannya harus lantang, tegas dan sambil menghunus kawali (wawancara, $29 \mathrm{Mei}$ 2015). Ritual osong hingga saat ini masih sering dilakukan untuk menjemput tamu-tamu terhormat.

Kawali sebagai asesoris pelengkap busana. Kawali yang digunakan sebgai pelengkap busana memiliki tampilan menarik karena dilihat oleh banyak orang. Busana lengkap orang bugis terdiri dari songko recca, jas tutup dan sarung sabbe, serta kawali terselip di pinggang kiri. Biasanya busana lengkap tersebut dipakai dalam acara-acara resmi, misalnya acara pertemuan kebudayaan, pernikahan atau upacara adat lainnya.

\section{Fungsi Religius}

Terdapat kepercayaan yang masih kuat di kalangan masyarakat Bugis bahwa kawali tertentu memiliki kekuatan magis atau tuah yang dapat memberikan pengaruh tertentu. Misalnya kawali yang berpamor daun padi (daung ase) digunakan dalam ritual maddoja bine. Maddoja bine adalah ritual begadang hingga pagi bersama benih padi (bine) yang sebelumnya telah direndam air. Dalam ritual itu kawali madaung ase ditempatkan disamping bine dan pelita. Hal itu dilakukan dengan harapan bahwa padi yang kelak akan ditanam menjadi subur, bebas dari gangguan hama sehingga nantinya kelak panen berlimpah (Pabittei, 1994:56; Hamid, 1990:31).

Selain dari fungsi ritual di atas, kawali tertentu juga dipercaya dapat menangkal atau penawar bagi orang yang kena penyakit "gunaguna", yaitu dengan cara meminum air yang sebelumnya diaduk dengan kawali yang dianggap bertuah (Andi Singke, wawancara 31 Juli 2015). Kawali juga sering digunakan orangorang tua, terutama ibu-ibu untuk menidurkan bayinya dengan cara menaruh kawali dalam ayunan bersama sang bayi. Hal itu dilakukan dengan harapan bahwa sang bayi dapat terhindar dari gangguan mahluk halus yang dapat mendatangkan penyakit. Hingga saat ini, di kalangan orang Bugis masih banyak yang menyimpan kawali di rumahnya sebagai penjaga rumah (pangonrong bola).

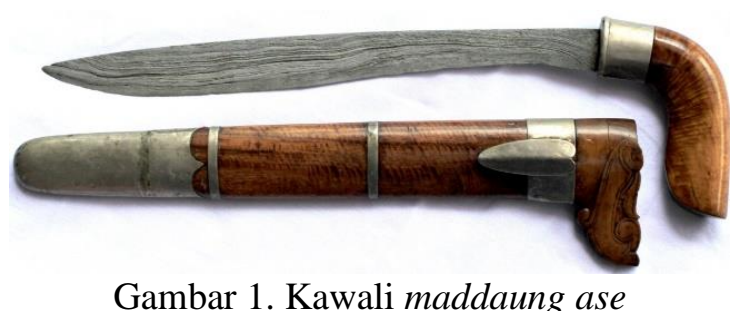
(Foto, Satriadi 2018) 


\section{Bentuk dan pamor kawali dalam masyarakat Bugis}

\section{Elemen kawali}

Sebagai karya yang utuh kawali memiliki karakteristik bentuk tersendiri sehingga dapat dibedakan dengan parewa matareng (Jawa: tosan aji) lainnya. Karya berupa kawali secara utuh terdiri dari tiga elemen pokok yaitu bilah (laca'), warangka (wanoa), dan hulu (pangulu). Kawali yang hanya terdiri dari bilah saja belum dapat dikatakan kawali, begitupun juga sebaliknya wanoa tanpa bilah atau pangulu tanpa bilah belum dapat disebut sebagai kawali yang utuh. Gambaran mengenai bentuk kawali/badik dijelaskan oleh Harsrinuksmo sebagai berikut:

Bentuk badik (kawali) hampir menyerupai pisau raut dengan bagian tajam hanya pada salah satu mata sisinya, yakni sisi depan. Ujungnya runcing. Tangkainya (hulu) dibuat dari kayu, gading, tulang, atau tanduk. Sarung badik (wanoa) terbuat dari kayu, biasanya trembalo. Banyak juga sarung badik yang dibuat dari kayu biasa, tetapi dilapisi dengan emas atau perak (Harsrinuksmo, 2004:80).

Keterangan di atas memberi gambaran bentuk kawali secara utuh yaitu terdiri dari bilah yang runcing, wanoa, dan pangulu. Elemenelemen tersebut merupakan satu kesatuan utuh untuk dapat disebut kawali. Berikut akan diuraikan elemen-elemen yang dimaksud.

\section{a. Bilah}

Bilah pada kawali merupakan bagian paling utama di antara bagian-bagian lainnya. Karena bilah menentukan jenis kawali, mamoso atau tidak, tempat munculnya pamor, dan tempat munculnya sisi'ketandaan. Secara umum jenis kawali berdasarkan bentuk bilahnya ada tiga yaitu raja, gecong, toasi dan luwu. Bagi seorang kolektor kawali, hanya dengan melihat bilah maka dia sudah dapat mengetahui jenis kawali itu. Perbedaan dari ketiga jenis kawali ini dapat dilihat dari laca' (bentuk bilah), sedangkan laca' ditentukan oleh recco' (ukuran perbandingan).

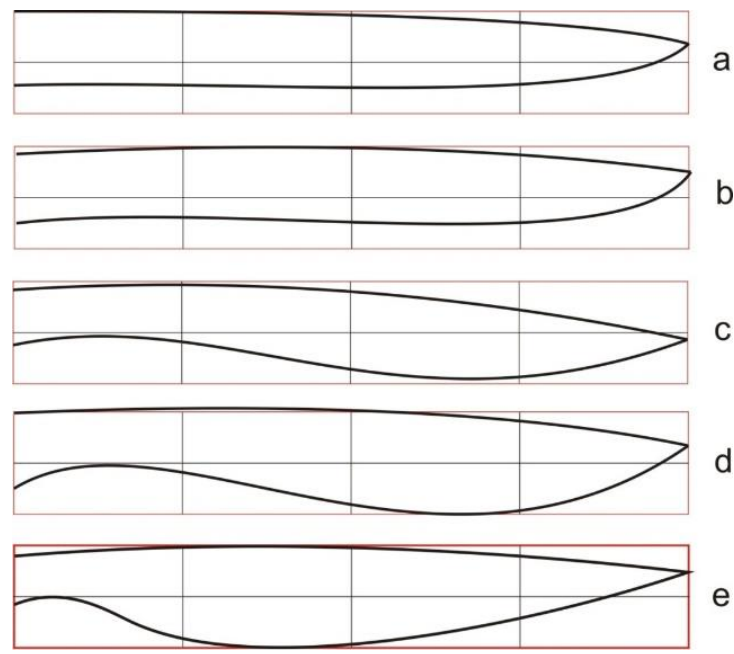

Gambar 2. Jenis laca' (bilah) kawali. (a) laca' lu', (b) laca toasi, (c) laca' gecong, dan (d) laca' raja dan (e) laca' mangkasara' (badi')

(Ilustrasi, Satriadi, 2018)

Laca' lu' merupakan bentuk bilah kawali yang paling umum digunakan di wilayah kerajaan Luwu sebagai kerajaan tertua di Sulawesi Selatan, dengan karakteristik bilah lurus (mirip keris lurus) dan tidak memiliki kallong dan "perut"-nya rata atau datar. Laca" toasi merupakan bilah kawali khas kerajaan Sawitto (sekarang Kabupaten Pinrang), sebuah kerajaan kecil yang berbatasan dengan kerajaan Luwu di sebelah utara (Andi Basri, wawancara, 2 Juni 2015). Laca' toasi memiliki karakteristik bilah yang hampir mirip dengan laca' $l u$ ', yang membedakan hanya pada bagian pangkal bilah yang memiliki kallong yang tidak terlalu melengkung sehingga sehingga menimbulkan sedikit lengkungan pada bagian perut. Laca' gecong merupakan bentuk bilah yang pertama dibuat di Addatuan Sidenreng (sekarang kabupaten Sidenreng Rappang), dengan karakteristik bilah yang lebih menunduk dan lebih lebar, serta kallong lebih kecil dari laca' toasi. Laca' raja merupakan bilah khas kerajaan Bone, dengan karakteristik perut lebih besar di antara laca' ugi lainnya dan maccingkallong (lihat gambar 2.1). Laca' mangkasara' merupakan bilah khas pada badi' (sebutan oleh orang-orang Makassar untuk Badik), dengan karakter perut besar sehingga biasa disebut dengan Badik Lompa battang (si perut besar) dan buncitnya lebih mendekati pangkal bilah. Jenis ini tidak banyak dibahas dalam tulisan ini karena merupakan senjata khas orang-orang 
Makassar, sementara tulisan ini membahas senjata tradisional Bugis.

\section{b. Wanoa}

Wanoa adalah salah satu bagian pada kawali yang berfungsi untuk melindungi bilah atau membungkus bilah. Biasa juga disebut sarung badik. Secara etimologi, wanoa berasal dari kata "wanua" berarti wilayah suatu negeri. Bagi orang bugis, wanua secara simbolik dianggap sebagai suatu wilayah terbatas pada diri manusia yang harus dikendalikan sendiri. Wanoa berfungsi sebagai pelindung bilah, dimana bilah dianggap sebagai personifikasi dari badan manusia.

Secara garis besar, ada tiga bagian utama wanoa, yaitu (1) bangi, secara etimologi bangi berarti dagu. Ketika kawali diselipkan di pinggang, maka bagian bangi selalu menghadap ke kanan dan condong ke arah pusar (posi). Arah kanan selalu dikonotasikan dengan segala hal-hal yang baik sedangkan posi dianggap sebagai sumber sumange' yang menjadi kekuatan yang hakiki dari setiap manusia. (2) pakkallasa' merupakan ikatan berupa cincincincin pada bagian tengah wanoa. Secara fisik fungsi pakkallasa' adalah untuk memperkuat wanoa, di sisi lain juga berfungsi simbolik. Pada zaman dahulu, jumlah pakkallasa' disesuaikan dengan status sosial pemiliknya dalam masyarakat (Dian Cahyadi, wawancara 28 Juli 2018). Di dalam masyarakat Bugis, salah satu cara mengetahui status seseorang dapat dilihat dari rumahnya, yaitu melihat bagian timpalaja

Wanoa yang baik biasanya terbuat dari kayu cendana (aju cendrana). Kayu cendana disamping memiliki tekstur garis yang indah juga dipercaya mengandung minyak alami yang baik untuk melindungi bilah dari karat. Bagian kayu yang paling baik adalah kayu yang berasal dari bagian pohon pangkal akar, paling bawah pohon (sekitar setengah meter dari pangkal akar, dan bagian atasnya 1,5 meter dari permukaan tanah) (Harsrinuksmo, 2011:517). Bagi orang Bugis bagian kayu seperti itu disebut dengan tampusu'. Di kalangan bangsawan Bugis atau orang berada (todeceng), wanoa keris, tombak, pedang, kawali, dan jenis senjata lainnya sering kali masih dihiasi lagi dengan lapisan logam dan permata. Biasanya yang digunakan untuk melapisi wanoa adalah emas, perak, atau kuningan. Wanoa yang seluruh permukaannya dilapisi dengan emas disebut dengan wanoa tatarapeng ulaweng sedangkan jika dilapisi perak disebut wanoa tatarapeng salaka dan sering ditambah hiasan batu permata. Lapisan wanoa yang tidak menutupi seluruh permukaan kayu (bagian bangi tidak tertutupi) disebut dengan wanoa pasangtimpo (Ubbe, 2011:72). Sedangkan wanoa yang diikat dengan gelang-gelang logam disebut dengan wanoa tabbu-tabbu (Andi Tenri Polojiwa, wawancara 1 Agustus 2015).

Timpalaja merupakan salah satu simbol status sosial dalam masyarakat Bugis. Susunan timpalaja paling banyak adalah berjumlah lima merupakan status paling tinggi yaitu arung yang memerintah atau lapisan keturunan raja (anakarung). Susun tiga untuk to-maradeka, sedangkan tanpa susunan atau timpalaja kosong berarti itu tempat tinggal ata (Pangeran, wawancara 17 Juli 2015).

Angka lima dikaitkan dengan pesan yang disampaikan "Orang Pintar di Luwu" (pasengna maccae ri luwu) kepada sang raja, bahwa lima hal yang harus diperhatikan sang raja agar tenang dalam kerajaannya, jujur (malempu), berhati-hati (makkalitutu), murah hati (masempo pangkaukeng), teguh pendirian (magetteng). Berani (warani) (Mallombasi, 2012:117-123).

Sedangkan angka tiga merupakan tiga pesan (paseng) yang juga dipesan oleh Maccae ri Luwu kepada anak cucunya/orang kebanyakan (to-sama), bahwa ada tiga hal dipakai memerintah negeri yaitu, orang yang diperintah menurut kesenangannya (cenning ati), diperintah orang dengan menjaga harga dirinya (siri') dan orang yang diperintah dengan menjaga ketakutannya (matau') (Mallombasi, 2012:124). Namun kini, jumlah pakkallasa' pada wanoa tidak lagi berdasarkan hal di atas. Pakkallasa' dijadikan elemen-elemen estetis untuk memperindah penampilan wanoa. Sehingga kadang ditemukan jumlah pakkallasa' lebih dari lima atau kurang dari tiga.

Kemudian bagian yang ketiga adalah pocci atau sepatu. Secara fisik pocci berfungsi untuk memperkuat dan sekaligus melindungi ujung bawah wanoa. Secara simbolik, pocci merupakan pengalas wanoa supaya tidak langsung menyentuh tanah. Hal itu dihubungkan dengan perlakuan khusus kepada para bangsawan Bugis, khususnya bangsawan yang memerintah, kemanapun ia pergi maka selalu ditandu oleh atanna, dengan kata lain tidak boleh menyentuh tanah.

\section{c. Pangulu}


Hulu sebagai pegangan senjata, oleh orang Bugis disebut pangulu. Secara etimologi, pangulu berarti pemimpin. Fungsinya sebagai pembungkus oting agar lebih nyaman digengam. Ada beberapa bentuk pangulu yang biasa digunakan dalam kawali yaitu pangulu rekko, pangulu kulu-kulu, dan pangulu calabai.

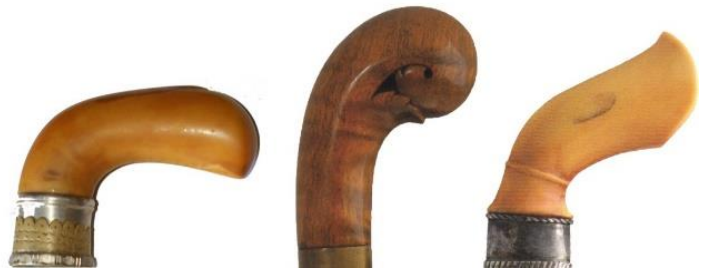

Gambar 3. Pangulu rekko, pangulu kulu-kulu, dan pangulu calabai.

(Foto Repro Satriadi, 2018)

Pangulu rekko merupakan simbol ketegasan seorang pemimpin. Bentuk pangulu rekko memiliki kemiringan antara $90^{\circ}-\leq 135^{\circ}$. Secara etimologi rekko berarti "menundukkan". Hal ini dihubungkan dengan kepercayaan orang Bugis bahwa kawali yang menggunakan pangulu rekko dapat menundukkan lawan, sehingga pangulu jenis ini biasanya banyak digunakan pada kawali dengan tujuan saling tikam (assigajangeng). Pada dasarnya, Pangulu rekko ditekuk (rekko) sebanyak tiga kali. Rekko tiga bermakna tiga hal yang harus dipegang oleh pemimpin, yaitu "aga mupikkiriki iya tonaro mu pau, aga mu pau iya tonaro mujama" (apa yang kamu pikirkan itu yang kamu ucapkan itu juga yang kamu lakukan), sementara orang Bone mengatakan "taro ada taro gau" (ucapan harus disertai dengan kelakukan) (Cahyadi, wawancara 28 Juli 2018). Hal serupa juga terdapat pada paseng yang berbunyi bahwa "sadda mappabati ada, ada mappabbati gau', gau' mappabbati tau (bunyi mewujudkan kata, kata mewujudkan perbuatan dan perbuatan mewujudkan manusia) (Mattulada,1998:85). Ungkapan-ungkapan tersebut merupakan ungkapan ketegasan dan cara berpikir cepat orang Bugis dalam mengambil keputusan. Sifat itu harus dimiliki oleh seorang pemimpin terutama pada setiap laki-laki, karena laki-laki merupakan pemimpin bagi keluarga, bangsa, bahkan bagi dirinya sendiri.

Di sisi lain, pangulu rekko merupakan simbolisasi seorang pemimpin yang tetap tunduk pada rakyatnya. Hal ini sesuai dengan konsep kepemimpinan orang Bugis yang pertama yaitu kepemimpinan to-manurung. Secara bentuk fisik, pangulu rekko lebih mendekati bentuk pangulu pada keris Bugis (tappi) yang berbentuk kepala burung laut, hal itu dikarenakan kehidupan masyarakat Bugis dikenal sebagai "suku bangsa pelaut". Burung laut merupakan lambang keberanian, lambang keselamatan, dan lambang keberhasilan. Kepala burung itu selalu menghadap frontal (Hamzuri, 1988: 39).

Pangulu kulu-kulu (kepala-kepalaan) merupakan pangulu kawali yang menyerupai bentuk kepala (ujungnya bulat). Pangulu jenis ini juga banyak digunakan pada parang (bangkung), dimana menurut penulis sendiri kawali merupakan bentuk minimalis dari bangkung, karena bentuk bilahnya sama, yang membedakan hanya ukuran dan cara penggunaannya. Jika kawali digunakan dengan cara tikam maka bangkung digunakan dengan cara tebas

Pangulu calabai, merupakan gabungan dari bentuk pangulu rekko dan pangulu kulukulu. Pangulu rekko memiliki kesan laki-laki (tegas) sedangkan pangulu kulu-kulu lebih berkesan feminim, sehingga ketika bentuk itu digabungkan maka menghasilkan bentuk calabai. Secara etimologis, calabai berarti orang yang berperawakan laki-laki dan perempuan. Hal itu mengingatkan kita pada bissu, yaitu seorang yang berperawakan seperti laki-laki dan perempuan dalam masyarakat Bugis. Sebelum Islam menjadi agama resmi orang Bugis (abad XVII) seorang bissu memiliki status sosial yang tinggi dalam kerajaan karena mereka memiliki peranan sebagai pendeta, dukun, serta ahli "ritual trance" (kemasukan roh), yang dalam bahasa Bugis disebut a'soloreng dan kini mereka bertugas untuk menjaga arajang. Mereka merupakan penghubung antara umat manusia dengan dunia dewata, serta memiliki pasangan mistis dari mahluk khayangan (Pelras, 2006: 97). Dalam hal ini, Bissu merupakan tokoh paradoks. Yang paradoks itu berupa bersatunya dua unsur yang saling bertentangan. Kondisi paradoks menghadirkan daya-daya transenden (descend power), yang tak nampak (mallinrung) hadir dalam simbol nampak (talle) (Sumardjo, 2010:218-220).

Selain bentuk-bentuk pangulu di atas, terdapat juga pangulu yang dipercaya memberikan keselamatan terhadap pemiliknya. Terutama ketika digunakan dalam kondisi yang membahayakan, misalnya saat terjadi perang, dikepung lawan, saat duel dan sebagainya. 
Mereka percaya bahwa pangulu dengan tandatanda khusus dapat membuat lawan tidak melihat, atau membuat lawan tidak bisa mencabut kawalinya. Dalam kepercayaan orang Bugis, terdapat ilmu pakuraga yaitu ilmu yang membuat lawan tidak dapat mecabut kawalinya, pangulu caredo merupakan pangulu yang dianggap dapat menangkal ilmu tersebut (Dray vibrianto, dalam Ubbe, 2011:170). Pangulu yang demikian mereka sebut pangulu mallinrung ri totona (bersembunyi di balik takdirnya) (Andi Basri, wawancara 2 Juni 2018). Pangulu caredo memiliki tanda-tanda khusus yaitu tonjolan yang keluar tepat pada bagian bawah yang melengkung. Biasanya terbuat dari kayu kemuning, kayu santigi, kayu trembalo, atau kayu hitam, yang melengkung secara alami (rekko kalena). Secara teknis, kayu dengan bentuk seperti itu tidak mudah pecah dan patah.

\section{Pamor kawali}

Pamor berasal dari akar kata amor atau wor yang berarti campur, atau bercampurnya beberapa unsur logam. Jadi pamor adalah lukisan pada tosan aji yang terjadi dari campuran beberapa unsur logam yang terbentuk dengan seni tempa (Prasida Wibawa, 2008: 14). Kata pamor dapat berarti bahan pencampur yang digunakan dalam pembuatan keris, dapat juga berarti teknik tempa lapisan pamor dan juga bisa diartikan 'jenis pola' yang tampak pada permukaan bilah keris (Haryoguritno, 2006:87)

Pamor dalam tosan aji menempati fungsi fisik sebagai tulang dari senjata atau tosan aji kemudian besi sebagai bahan pengikat, sementara baja merupakan penajam bilah. Selain sebagai tulang dari senjata, pamor juga sebagai motif hiasan tosan aji dan juga sebagai hiasan dan fungsi simbol metafisis (Zazuli, 2004:15). Pamor sengaja ditambahkan sebagai ornamen yang melekat pada bilah keris ataupun jenis tosan aji lainnya. Sebagai produk kesenian, ornamen juga merupakan produk budaya. Ornamen merupakan ekspresi gagasan, sikap dan perilaku masyarakat. Sebagai sistem budaya ornamen merupakan model untuk berperilaku, ornamen mengusun pesan-pesan sosial, moral, religi dan bahkan politis. Sebagai model dari perilaku, ekspresi ornamen bersifat khas berdasar pada eko-budaya, sosio-budaya, dan religio-budaya masyarakat pemiliknya. Oleh karena itu ekspresi ornamen disuatu daerah berbeda dengan daerah lain berbeda pula antara etnik yang satu dengan etnik yang lainnya (Guntur, 2004).

Haryono Haryoguritno kemudian menjelaskan manfaat dari pamor yakni sebagai berikut:

"Pamor memberi manfaat teknis, estetis, filosofis, simbolis dan spiritual. Manfaat teknis karena bahan pamor merupakan salah satu unsur penguat struktur pada bahan yang direkayasa, terutama dengan lapisan-lapisan sejajar. Selain itu, pola gambar lapisan pamor yang muncul pada permukaan bilah keris akan memperindah penampilannya, sekaligus menambah wibawa kerisnya. Keindahan pola pamor pada permukaan bilah keris menjadi salah satu kriteria untuk menilai mutu keris. Ini berarti bahwa pola pamor juga memberikan manfaat estetis. Dan yang terakhir, pola pamor itu seolah-olah melambangkan kekuatan spritual dalam keris itu" (Haryoguritno, 2006:198).

Pamor dalam istilah bugis disebut ure'. Ure' secara etimologi berarti "urat" (Ubbe,dkk. 2011: 92-93). Ure' dalam bentuk pamor kawali tampak seperti guratan-guratan kasar membentuk garis lurus, lengkung, ataupun menyudut. Bentuk-bentuk pamor pada bilah kawali yang sekarang merupakan tiruan-tiruan bentuk yang pernah diciptakan oleh panre sebelumnya. Dharsono menyebut hal ini sebagai karya sanggit, yaitu bentuk reproduksi dengan inovasi garap dengan mengacu pada konsep revitalisasi (Dharsono, 2015:100). Karya-karya kawali yang dibuat sekarang tetap mengacu pada karya lama oleh karena dianggap sudah baku dan tidak perlu dirubah lagi.

Pamor pada kawali pada umumnya lebih banyak berupa pamor-pamor yang tergolong pamor tiban atau tanpa direkayasa (ure' tuo). Yang berpamor rekan (ure a'kebbureng) relatif lebih sedikit. Ure' tuo pada kawali yang paling banyak dan populer adalah pamor tebba jampu, dan pamor balo pakke. Sedangkan jenis ure' a'kebbureng yang biasa dijumpai adalah teknik pamor rekan miring (ure' tapping) dan pamor rekan puntiran (ure' kurissi), misalnya pamor maddaung ase, pamor gemme silampa, pamor kurissi daun kaluku, dan lain sebagainya.

1. Pamor tiban (Ure’ Tuo) 
Ure' tuo yaitu teknik dasar pembuatan pola pamor dengan cara penempa tanpa maksud membuat pola tertentu, cukup apa saja jadinya saja, hampir tanpa rekayasa. Hasil akhir pamornya non-figuratif atau tanpa pola. Bagi masyarakat Bugis tidak mengenal istilah "pamor tiban", akan tetapi lebih mengenal istilah ure' tuo (pamor hidup). Ure' dalam istilah lokal berarti akar, yang menurut mereka bahwa pada hakikatnya besi itu memiliki ure' (akar) seperti pohon. Orang-orang Bugis sangat menyukai bahkan mencari kawali "makkure". Motif pamor pada kawali tidak dapat ditentukan oleh panre akan tetapi ditentukan oleh "Api Dewata" (Andi Basri, wawancara Agustus 2018). "Api Dewata" dalam hal ini adalah kehendak Yang Maha Kuasa, sehingga tempaan oleh api dewata dianggap sebagai were dari Allah SWT yang wajib disyukuri. Were merupakan pandangan hidup orang Bugis yang mengatakan bahwa resopa temmangingi malomo naletei pammase dewata (hanya dengan keras tanpa putus asa yang akan memperoleh hidayah Dewata). Paseng tersebut merupakan dasar pengharapan dan semangat kerja orang-orang Bugis dalam mengarungi kehidupan ini.

Lebih lanjut dikatakan oleh Andi Basri bahwa pamor khas pada kawali yang tergolong tiban, yaitu pamor balo pakke dan tebba jampu" (wawancara 2 Juni 2018). Hal serupa juga dipertegas oleh Andi Darwis bahwa

“...namo maga gellona pamoro'na kawalie narekko degaga pamoro tuo na, padai bessi biasa. Iyaro riyaseng $E$ pamoro tuo mattebba pada jampue pamoro'na mapute pada salaka e, iyatosi ise'na ure tuo mapute pada jarung ko pallawangenna baja'e na bessi laloe. (sebagus apapun pamor kawali jika tidak mempunyai pamor hidup maka sama saja dengan besi biasa, yang dimaksud dengan pamoro tuo motifnya seperti pohon jambu dan warnanya putih seperti besi putih, sementara isi dari pamoro hidup adalah berwarna putih berserat yang biasa muncul di sela baja dan besi) (Andi Darwis, dalam Rustam, 2013).

Berdasarkan data di atas, dapat dikatakan bahwa pamor tiban pada kawali dikenal oleh masyarakat Bugis sebagai "ure' tuo", berwarna putih seperti perak, dan kelihatan berserat muncul di antara besi dan baja. Ure' tuo dijadikan sebagai indikasi bahwa kawali itu memiliki kualitas yang baik. Yang termasuk ure' tuo pada kawali memiliki motif seperti belahan kayu jambu (tebba jampu) dan belang tokek (balo pakke). Andi Ancu menambahkan bahwa pamor "batu" merupakan pamor yang pertama dibuat oleh para panre terdahulu, karena langsung mengolah biji besi dari batu. Kemudian disusul dengan penemuan pamor dato'-dato', balo pakke dan tebba jampu (wawancara 1 Agustus 2018).

2. Pamor rekan (ure' ebbureng)

Pamor rekan dalam istilah Bugis disebut sebagai ure' akke'bu-kebbureng atau ebbureng berarti sesuatu yang dibuat-buat atau dirancang. Ure' ebbureng merupakan pamor yang sebelumnya direkayasa, sehingga menghasilkan motif sesuai dengan yang diinginkan, biasanya menghasilkan motif figuratif. Pamor rekayasa merupakan penguasaan atau keterampilan pencampuran logam yang dapat dikontrol, keterampilan ini ditemukan oleh panre/mpu berdasarkan pengalamannya dalam membuat pamor tiban sehingga timbullah ide untuk membuat motif tertentu pada bilah pusaka (Andi Ancu, wawancara 1 Agustus 2018). Pembuatan ure' ebbureng banyak dilakukan ketika We Tadangpali berhasil sembuh dari penyakit yang dideritanya, jadi sebagai bentuk kegembiraan atas kesembuhan itu maka dibuatlah pusaka-pusaka yang tampilannya cantik termasuk pamornya, sebagaimana kecantikan We Tadangpali (Andi Basri, wawancara 2 Agustus 2018).

Data tersebut bersumber dari cerita mitologi tentang putri Datu Luwu yang dibuang karena penyakit yang dideritanya. Sementara jika menelusuri perkembangan kerajaan Luwu, ditemukan adanya hubungan dengan kerajaan Majapahit secara intensif sebagai penyuplai besi dan bahan pamor untuk membuat senjata atau tosan aji. Hubungan ini kemudian lebih diperkuat dengan menjaling hubungan keluarga antar kedua kerajaan dengan perkawinan. Interaksi-interaksi yang intensif dilakukan antar kedua kerajaan tersebut menimbulkan terjadinya akulturasi budaya Jawa dan Bugis, termasuk penyebaran pamor rekan dari Jawa. Hal ini dapat dilihat pada kawali Luwu yang lebih dominan pamor rekan yang diterapkan pada bilah kawali.

"berdasarkan Nagara Kertagama dan sumber-sumber naskah lokal serta toponimi yang dijumpai di Luwu, ada 
dugaan kuatnya relasi antara Mahapahit dan Luwu di masa lalu. Relasi inilah yang diduga menimbulkan irisan penggunaan bahan baku dan teknologi dalam pembuatan tosan aji di antara dua kebudayaan ini. Tak hanya mengirim bahan baku besi-nikel ke JawaMajapahit, namun sejumlah pandai besi dari Jawa diperkirakan bermukin di kawasan Luwu menandai intensifnya interaksi antara kedua peradaban ini" (Arif dalam Saptono (ed), 2015: 37).

Dalam pembuatan pamor rekayasa pada bilah kawali dikenal ada tiga cara, yaitu teknik lonjo', teknik tapping, dan teknik kurissi. Teknik lonjo' merupakan teknik penyusunan bala-bala pamor dengan posisi sejajar dengan inti baja. Teknik tapping merupakan penyusunan bala-bala pamor dengan posisi tegak lurus terhadap inti baja. Sedangkan teknik kurissi biasa juga disebut teknik puntir yaitu teknik pembuatan pamor dengan cara memutar bala-bala pamor.

\section{Makna simbolik motif pamor kawali}

Estetika nusantara selalu berkaitan dengan nilai tontonan (keindahan) dan nilai tuntunan (falasafah) dan dipengaruhi oleh sugesti alam. Motif pamor pada bilah kawali selain sebagai penghias pada bilahnya juga mengandung makna filosofis yang dijadikan pedoman masyarakat Bugis.

1. Motif tebba' jampu adalah motif pamor berupa garis-garis tak beraturan. tebba јатри itu merupakan simbol kekuatan sebagaimana kuatnya kayu jambu. Bentukbentuk pada jambu diterapkan dalam bentuk pamor kawali karena batang jambu biji memiliki karakter yang nampak pada kulitnya. Kulitnya pun memiliki karakter khas yaitu apabila kulitnya lepas maka akan muncul lagi kulit yang baru" (wawancara 21 November 2015).

2. Motif ma'dato'-dato adalah motif berupa gumpalan-gumpalan menyerupai datodato atau awan yang hampir memenuhi permukaan bilah motif. Pamor dato'dato'/ awan yang ada pada bilah kawali merupakan simbol pengharapan akan datangnya berkah dari langit sehingga kehidupan akan terus berlanjut. Sehingga harapan-harapan itu pun diaplikasikan dalam bentuk pamor kawali dengan maksud supaya pemiliknya bisa bermanfaat dalam masyarakat.

3. Motif balo pakke adalah motif berupa belang-belang yang menyerupai kulit binatang tokek. pakke itu binatang yang disakralkan oleh masyarakat Bugis, karena memiliki kemampuan melekat yang luar biasa. Apapun yang melekat pada kakinya akan sulit untuk dilepas, oleh karena itu pakke dijadikan sennuangen untuk pemikat atau daya tarik, sehingga pada zaman dahulu kawali yang berpamor balo pakke hanya dimiliki oleh bangsawan Bugis dengan harapan agar dicintai oleh rakyatnya" (Kahar Wahid, wawancara 21 November 2015).

4. Motif pesse' pelleng adalah motif melingkar di bagian tengahnya yang mirip bekas sidik jari, motif tersebut memenuhi permukaan bilah dari pangkal hingga ujung. Pesse pelleng adalah lampu yang digunakan oleh orang-orang Bugis dulu untuk penerangan. Dibuat dengan balutan dedak pada potongan bambu dengan cara di pijit-pijit dengan jari-jari (ripesse'pesse). Jika pesse pelleng diterapkan pada kawali sebagai bentuk motif, maka itu berarti simbol penerangan. Karena orangorang Bugis dulu selalu menjadikan sennusennuangeng sebagai harapan (Kahar Wahid, wawancara 21 November 2015).

5. Motif ma'daung ase adalah motif berupa lapisan-lapisan garis memanjang bersusun dari pangkal hingga ke ujung bilah. Motif daung ase merupakan simbol kesuburan. Padi (ase) bagi masyarakat Bugis adalah simbol kehidupan dan kesejahteraan.

6. Motif mata tedong adalah motif berbentuk spiral yang direpetisi dari pangkal hingga ujung bilah. Tedong melambangkan kesabaran dan keuletan dalam bekerja, serta simbol kesuburan. Dalam hal ini, pamor bermotif mata tedong sebagai sennuangeng (makna simbolik) bahwa pemilik kawali tersebut diharapkan memiliki sifat sabar, pekerja keras, dan patuh pada aturan atau panggadereng, baik dia sebagai pemimpin dalam keluarga maupun sebagai orang yang dipimpin dalam masyarakat. Ajaran ini juga dapat ditemukan dalam paseng to riolo bahwa "resopa temmanginngi, namatinulu, malomo naletei pammase Dewata" (hanya 
dengan kerja keras, tanpa putus asa, akan memperoleh hidayah yang maha kuasa).

7. Motif sikadoi adalah motif berupa garis lengkung yang saling berhadapan. Dalam bahasa Bugis, "sikadoi" diartikan "saling menganguk". Saling mengangguk berarti saling menyetujui. "...sikadoi itu berarti dua orang atau lebih yang kado' atau saling menyetujui. Biasanya orang Bugis menggunakan kawali yang berpamor "ure sikadoi" untuk pergi melamar dengan harapan agar lamarannya diterima" (Kahar Wahid, wawancara 21 November 2015).

8. Motif gamacca adalah motif utama berupa garis zigzag dengan pola berderet ke ujung bilah dengan bentuk dasar segitiga bersusun timbal balik. Gamacca' dalam bahasa Bugis berarti anyaman bambu. Dalam arsitektur rumah Bugis gamacca' sering digunakan sebagai dinding (pelindung). Sementara dalam ritual-ritual religi, gamacca' merupakan bahan dari pembuatan walasuji, sehingga sebagian masyarakat juga menyebutnya sebagai ure' walasuji

9. Motif ma'daung kaluku adalah motif pamor dengan bentuk garis-garis rapat dengan arah diagonal yang bertemu pada bagian tengah bilah. Daun kelapa itu merupakan simbol kebersamaan (assiolompolongeng), karena daun-daun kelapa yang banyak itu semua berpegangan pada ruasnya. Itulah yang dijadikan simbol oleh orang-orang Bugis untuk terus menjaga tali persaudaraan sebagaimana daun-daun kelapa tidak jatuh atau lepas dari ruasnya" (Kahar Wahid, wawancara November 2015).

10. Motif bunga majang adalah motif segi empat yang setiap sisinya melengkung ke dalam sehingga menyerupai bintang segi empat. Dalam kehidupan sehari-hari orang Bugis, bunga majang merupakan hal yang paling penting terutama dalam upacara daur hidup, yaitu kelahiran, pernikahan dan kematian. Pada acara tersebut bunga majang selalu dihadirkan sebagai pelengkap upacara ritual. Pada upacara aqiqah (maccera' ana'), bunga majang dihadirkan sesaat setelah sang anak lahir, sementara dalam acara pernikahan (ma'pabbotting), bunga majang digunakan untuk air mandi calon penganting, dan pada saat upacara kematian pun bunga majang digunakan untuk memandikan mayat

11. Motif daung alosi (daun pinang) adalah motif berupa lapisan-lapisan garis diagonal berkelompok. Karakteristik daung pinang adalah ruas daun yang naik dan turun secara berselang-seling (atas-bawah) yang maknanya sama dengan pepatah Bugis yang mengatakan "siselle-selle muto aje we lo riolo" (kaki itu bergantian maju mundur ke depan dan belakang). Hal itu bermakna saling tolong menolong, karena manusia sebagai mahluk sosial tetap membutuhkan bantuan dari orang lain. Selain itu juga bermakna rebba sipaoto' $i$, malilu sipakainge, mali siparappe (jatuh saling membangungkan, khilaf saling mengingatkan dan hanyut saling meraih) artinya saling mengingatkan dalam kebaikan dan tidak egois dalam segala hal.

12. Motif mattulu tellu, merupakan motif yang mirip bentuk "bunga majang" tapi ukuran lebih kecil, memanjang dan tersusun sebanyak tiga buah yang oleh masyarakat Bugis disebut dengan ure' mattulu tellu (pamor pilin tiga tali). Tulu (tali) sering dihubungkan dengan ikatan yang bermakna ketegasan yang harus dimiliki oleh seorang laki-laki Bugis. Jumlah tiga tali disini bermakna simbol ketegasan dalam tiga hal, yaitu "aga mupikkiriki iya tonaro ти pau, aga pura ти pau iya tonaro mujama" (apa yang kamu pikirkan itu yang kamu ucapkan itu juga yang kamu lakukan). Pepatah tersebut merupakan ungkapan ketegasan yang mengandung pesan supaya pikiran, perkataan dan perbuatan itu sejalan.

13. Motif boting cala' adalah motif berupa guratan berbentuk huruf " $S$ ". Jacob Sumardjo menyebut motif seperti itu dengan "pola dua berbalikan". Motif huruf "S" adalah motif paling tua di Indonesia, karena motif tersebut telah ada pada zaman prasejarah (Sumardjo, 2010:223). Lebih lanjut, Jacob Sumardjo mengatakan bahwa motif huruf "S" atau huruf "S" terbalik ini, simbol dari bentuk paradoks lakiperempuan yang bermakna jamak. "boting cala", secara harpiah "boting" berarti menikah, atau pernikahan antara laki-laki dan perempuan atau gabungan dari dua unsur yang berbeda. sedangkan "cala" dalam masyarakat Bugis berarti laki-laki 
palsu (calalai), laki-laki yang berwatak seperti perempuan atau perempuan palsu (calabai). Jadi "boting cala" berarti dua watak yang berbeda, yaitu laki-laki dan perempuan, hal ini sejalan dengan penjelasan Jacob Sumardjo di atas. "boting cala" menunjukkan dua pola atau watak yang berbeda akan tetapi saling memenuhi. Karena manusia itu dualistik, yakni merupakan pasangan kembar yang saling bertentangan tetapi komplementer, maka dua alam yang lain juga demikian. Inilah sebabnya simbol lelaki dan perempuan amat domian (Sumardjo, 2010:234).

14. Motif lataring tellu adalah motif berupa bulatan kecil berjumlah tiga yang terletak pada pangkal bilah. Lataring tellu sering dihubungkan oleh masyarakat dengan citacita kesatuan antara tiga kerajaan besar Bugis Bone, Soppeng dan Wajo, yang menyatukan diri melalui perjanjian tellung poccoe (tiga puncak: Bone, Soppeng dan Wajo) untuk membebaskan diri dari kekuasaan Gowa dan VOC (Ubbe, 2011:102). Hal tersebut dipertegas oleh Kahar Wahid, bahwa "angka tiga dalam kepercayaan orang Bugis merupakan simbol kekuatan. Sebagaimana kaki meja yang berjumlah tiga, kesemua kakinya menopang, tidak ada kaki yang istirahat" (wawancara 21 November 2015).

15. Motif taiganja adalah stilisasi kelamin perempuan (Ubbe, 2011:328). Menurut Jacob Sumardjo, motif seperti itu merupakan motif pilin berganda atau pengembangan dari motif dasarnya berbentuk huruf "S" (2010:225). Namun pada motif taiganja, pengulangan bentuk "S" dibuat dengan saling membelakangi. Motif taiganja merupakan gabungan dari simbol laki-laki dan perempuan (simbol dualistik). Sehingga disebut juga dengan simbol paradoks. Gabungan dari laki-laki dan perempuan dalam masyarakat Bugis disebut dengan "cala" (lihat pembahasan mengenai simbol "boting cala"), yaitu manusia bissu, yang dikenal dengan manusia kebal. Simbol tersebut sama maknanya dengan simbol huruf "S" (boting cala) pada pembahasan sebelumnya, yaitu sebagai tula' bala.

\section{Simpulan}

Kawali merupakan wujud kebudayaan masyarakat Bugis. Setiap elemen-elemen kawali menggambarkan nilai-nilai kebudayaan Bugis. Pangulu menggambarkan kepemimpinan orang Bugis yang tegas. Wanoa dianggap sebagai wilayah tempat pemimpin mengatur masyarakatnya. Bilah merupakan bagian paling pokok karena di dalamnya terdapat pamor yang menggambarkan nilainilai falsafah orang Bugis. pamor kawali menggambarkan nilai kehidupan yang ideal yaitu kekayaan (abbaramparangeng), kepemimpinan dan kemuliaan (arajangeng), keselamatan (asalamakeng), kelaki-lakian (arowanengeng), kerukunan dalam rumah tangga (alaibinengeng). Kelima point utama tersebut merupakan faktor yang paling menentukan siri' (harga diri dan kehormatan) seseorang, karena bagi orang Bugis, siri' merupakan ideologi tertinggi yang dipegang teguh oleh semua etnis di Sulawesi Selatan, khususnya Bugis. sehingga mereka mengatakan siri' e mi riongroang lino, hanya karena siri' kita hidup di dunia.

\section{Daftar Pustaka}

Arif, Ahmad. Besi Luwu, Pasang Surut Metalurgi Nusantara, dalam Hariadi Saptono (ed). Keris dan Senjata Pusaka Bahari. Jakarta: Bentara Budaya Jakarta, 2015, hlm. 31-50.

Dharsono, Estetika Nusantara. Surakarta: Institut Seni Indonesia Surakarta, 2015.

Dray Vibrianto, "Kawali Tanah Bugis" dalam Ubbe, Ahmad. Pamor dan Landasan Spiritual Senjata Bugis. Jakarta, Gramedia Pustaka Utama, 2011.

Ewa, Tenri. Pamor Senjata Pusaka Sulawesi Selatan Dan Maknanya", Makassar: Penerbit Buku.com, 2014.

Guntur. Studi Ornamen, sebuah pengantar, cetakan I. Surakarta: STSI Press, 2004.

Hamid, Senjata Tradisional Sulawesi Selatan. Jakarta: Departemen Pendidikan Dan Kebudayaan, 1990. 
Satriadi, Bentuk, Fungsi, Dan Makna Pamor Senjata Kawali Dalam Masyarakat Bugis, hlm. 12-27

Hamzuri. Keris. Jakarta: Djambatan, 1988.

Zazuli, Achmad. Pamor Eksotik Tosan Aji. Solo: CV. Aneka, 2004.

Harsrinuksmo, Ensiklopedi Keris. Jakarta: PT. Gramedia Pustaka, 2011.

Haryoguritno, Haryono. Keris Jawa, Antara Mistik dan Nalar. Jakarta: PT Indonesia Kebanggaanku, 2006.

Koentjaraningrat. Pengantar Ilmu Antropologi. Jakarta: Aksara Baru, 1986.

Mattulada, Latoa: Suatu Lukisan Analisis Terhadap Antropologi Politik Orang Bugis. Makassar: Hasanuddin University Press, 1995.

Mattulada, Sejarah, Masyarakat dan Kebudayaan Sulawesi Selatan. Makasar: Hasanuddin University Press, 1998.

Pabittei, Badik Sulawesi Selatan. Bagian Proyek Pembinaan Permuseuman Sulawesi Selatan, 1994.

Palloge, Sejarah Kerajaan Tanah Bone. Makassar: Dinas Kebudayaan dan Pariwisata Sulawesi Selatan. 1990.

Pelras, Christian. Manusia Bugis. Terj. Abdul Rahman Abu, Hasriadi dan Nurhady Simorok. Forum Jakarta-Paris, Ecole Francais D'extreme-Orient. Jakarta: Nalar, 2006.

Rustan. "Kawali, Identitas Laki-Laki Bugis" Skripsi S1 Karya Film Dokumenter, Ilmu Komunikasi Fakultas Ilmu Sosial dan Ilmu Politik Universitas Hasanuddin, 2013.

Sumardjo, Jakob. Estetika Paradoks. Bandung: Sunan Ambu, 2006.

Satriadi, 2016. Kawali dalam masyarakat Bugis (tesis) . Surakarta: ISI Surakarta.

Ubbe, Ahmad, Andi M. Irwan Zulfikar dan Dray Febriyanto Senewe. Pamor dan Landasan Spiritual Senjata Bugis. Jakarta, Gramedia Pustaka Utama, 2011. 
Jurnal Pakarena, Volume 4 Nomor 1, Juni 2019 